\title{
Çeviri Sürecinde Kendi Kararlarını Verebilen Çeviri Öğrencilerine Yönelik Bir Uygulama Örneği
}

\section{Aslı ARABOĞLU1}

\begin{abstract}
$\ddot{\mathbf{O} z}$
Çeviri eğitiminin başlangıcında, birçoğumuzun karşılaştığı sorunların başında öğrencilerin çeviriye karşı çekinceli yaklaşımları gelir. Sınıf içinde, gerek çeviri sürecinden önce gerekse yaptıkları çevirilere dair dönütlerin verilmesi esnasında sordukları bazı sorular bu yaklaşımlarını ön plana çıkartmaktadır. Bu sorulardan bazıları: “Kaynak metinden ne kadar uzaklaşmalıyım?”, "Kendi yorumlarımı katarak çevirdiğimde yazara haksızlık etmiş olmaz mıyım?”, "Kaynak metindeki kültürel öğeleri çevirdiğimde bu yeni bir metin olmaz mı?” şeklindedir. Bu çekinceli yaklaşımın üstesinden gelmenin yolu ise öğrencilerin temel çeviri gerçeklerini öğrenmelerinden ve çevirinin doğası gereği belirli bağlamlar içerisinde gerçekleşen bir yorumlama işi olduğu bilincini edinmelerinden geçtiği söylenebilir. Bunun yanı sıra, çeviri pratiği yoluyla, geleceğin çevirmenleri olarak öğrencilerin, kendi kararlarını vermelerini ve çeviri işinin getirdiği sorumlulukları almalarını ve yaptıkları çevirileri düşüncelerinin birer yansıması olarak görmelerini sağlamanın çeviri eğitiminin başındaki ilk hedeflerimizden olduğu söylenebilir. Bu çalışmanın amacı, yukarıda belirtilen sorunsal çerçevesinde, öğrencilerin çeviriye karşı çekinceli yaklaşımlarını ortadan kaldırmaya ve çeviri sürecinde kendi kararlarını alabilmelerine yönelik örnek bir uygulama sunmaktır. Bu kapsamda öğrencilerin görev bağlamında yaptığı "Names" adlı bilgilendirici metin türünde ancak kültürel öğeleri barındıran metnin çevirileri ve çeviri sürecinde nasıl karar aldıkları değerlendirilecektir.
\end{abstract}

Anahtar kelimeler: Çeviri, Çeviri eğitimi, çevirmen kararları, çeviri süreci, çeviri pratiği.

\section{Sample of a Practice for Translation Students Who Can Take Their Own Decisions}

\begin{abstract}
In the beginning of translation education, hesitative attitude of students to translation is foremost among many problems we encounter. At the classroom, questions that they ask both before translation process and during giving feedback to their translations bring these attitudes forefront. Some of these questions are: "How far can I move away from source text?", "Aren't I unfair to the author when I translate by adding my own interpretation?”, “Isn't it a new text when I translate cultural elements in the source text?" It can be said that for students, the way to overcome these hesitative attitudes is to learn translation facts and to gain the awareness that translation is an act of interpretation by its nature. Besides, it can be said that one of the initial objectives of us in the beginning of translation education is, with translation practices, to enable the students, as future translators, to make their own decisions and also take responsibilities that translation brings and to see their translations as a reflection of their views. The aim of this study is, in the frame of abovementioned problem, to present a sample of practice to enable the students avoid their hesitative attitudes to translation and make their own decisions in the process of translation. In this context, the text titled "Names", which is informative and which also includes cultural issues was translated
\end{abstract}


in a context of a duty by students. The paper will show examples from the translations and evaluate how they make decisions during the translation process

Key words: Translation, translation education, translator decisions, translation process, translation practices.

\section{Giriş}

Çeviri eğitiminin başlangıcında, birçoğumuzun karşılaştığı sorunların başında öğrencilerin çeviriye karşı çekinceli yaklaşımları gelmektedir. Genel metinler çevirisi, çeviriye giriş gibi derslerde öğrencilere, gerek çeviri sürecinden önce gerekse yaptıkları çevirilere dair dönütlerin verilmesi esnasında çeviri yaparken ne tür zorluklar yaşadıkları, bu zorlukların üstesinden gelmek için ne tür yöntemler kullandıkları sorulduğunda çoğunlukla, yanlış yapmış olduğunu düşünme baskısı altında çekinceli yaklaşımlarla yanıtlar verdikleri söylenebilir. Bu çalışmanın da çıkış noktasını oluşturan bu çekinceli yaklaşımların üstesinden gelebilmek için öncelikle kararsızlıkları ya da endişelerini dile getiren ifadelerini yazılı hale getirmek bu çekinceleri ve sorunu daha açı bir şekilde ortaya koymalarını sağlayacaktır. Bu nedenle öğrencilerden çekincelerini, isimlerini yazmadan yazılı hale getirmeleri istenmiş ve onlara şu soru sorulmuştur: "Çeviriye yeni başladığınızda yaşadığınız kaygıları sorularla ifade edebilir misiniz?” (2018 Mart). Öğrencilerin yanıt olarak sundukları ifadeler birbirine oldukça benzer niteliktedir. Oluşturdukları sorulardan bazıları şu şekildedir:

- \%10o doğru çeviri var mıdır?

- Erek Metin ile Kaynak Metin \%10o eşdeğer midir?

- Doğru çeviri / yanlış çeviri diye bir şey var mıdır?

- Kime, neye hizmet etmesi için çeviriyorum? Amacım ne?

- Erek metin çevirilerimizde sınırlarımız haklarımız nereye kadar olabilir?

- Kendi yorumlarımı katarak çeviri yaptığımda yazarın metninden uzaklaşmaz mıyım?

- Yazarın ifadelerini değiştirmek yazarlığa soyunmak olmaz mı?

- Kaynak metne bağlı kalmaya çalışırken erek okuyucu kitlesini göz ardı etmiş olur muyum?

- Kaynak metni erek metne çevirirken nasıl bir yol izlemeliyim? Ne kadar uzaklaşmam doğru olur?

- Kültürel kavramları nasıl aktarabilirim?

- Nasıl, kaynak metnin tam karşılığı olan bir çeviri yapabilirim?

- Çeviriye ne kadar sadık kalmalıyım?

- Acaba bu cümleden, benim anladığımı mı çevirmeliyim, yoksa kaynak metindeki sözcükleri mi aktarmalıyım?

- Çeviri bir eser ne kadar güvenilirdir?

Yukarıdaki sorularda öğrencilerin çoğunlukla tam anlamıyla ve kesin çizgilerle belirlenmiş bir çözüm arayışında olduğu görülmektedir. Bu arayışın nedeni doğası gereği kesin sınırları belirli olmayan çeviri sürecine dair yeterli kuramsal bilgiye, çeviri bilgisine sahip olmamalarından kaynaklanıyor olabilir. Yukarıdaki sorularda da izlenen bu çekinceli yaklaşımın üstesinden gelmenin yolu ise öğrencilerin temel çeviri gerçeklerini öğrenmelerinden ve çevirinin doğası gereği belirli bağlamlar içerisinde gerçekleşen bir yorumlama işi olduğu bilincini edinmelerinden geçtiği söylenebilir. Ancak bu bilinci edinecekleri süreç kısa zamanda kat edilecek bir yol değildir. Çekincelerinin büyüyüp ciddi ön yargılara dönüşmemesi ise her öğrenim sürecinde olduğu gibi çeviri eğitiminde önem arz etmektedir. Bu durumda, yeterli çeviri bilgisine sahip olmadan önce düşüncelerine hâkim olan soyut bir çeviri 
kavramını somut olan çeviri işine dönüştürebilmek için belirli bağlamlardan ve görevlerden yararlanmak kaçınılmaz görünmektedir. Çevirmenin amacını odak noktasına alan Hans J. Vermeer’in kuramsal görüşü, çevirinin önce belirli bir bağlam ve görev doğrultusunda yapılmasının gerekliliğini bize sunmaktadır. Ayşe Nihal Akbulut, Vermeer'e gönderme yaparak bir bağlam doğrultusunda gerçekleşen çeviri sürecinin karmaşık ve devingen yapısının olmazsa olmaz parçalarından şöyle bahseder:

“Çeviri dilsel bir görüngü, bir iletişim olgusu, özgülleşmiş ve toplumsal bir insan davranışı olduğundan her eylem gibi bir amaca yönelik olarak gerçekleşir. Çeviri süreci, çevirinin amacı, çevirinin içinde oluştuğu koşullar ve çevirinin yapılmasını öneren, yani süreci başlatan etkenden oluşan bir sacayaktan bağımsız düşünülemez” (Akbulut, 2004, s 134).

Öyleyse, somut bir çeviri işinin belirli bir bağlam çerçevesinde gerçekleşeceğini ortaya koymak çeviri pratiği yoluyla mümkün olabilir. Geleceğin çevirmenleri olarak öğrencilerin, kendi kararlarını vermelerini ve çeviri işinin getirdiği sorumlulukları almalarını ve yaptıkları çevirileri düşüncelerinin birer yansıması olarak görmelerini sağlamanın çeviri eğitiminin önemli hedeflerinden olduğu söylenebilir. Bu çalışmanın amacı, yukarıda belirtilen sorunsal çerçevesinde, öğrencilerin çeviriye karşı çekinceli yaklaşımlarını ortadan kaldırmaya ve çeviri sürecinde kendi kararlarını alabilmelerine yönelik örnek bir uygulama sunmaktır.

Bu kapsamda, öncelikle, çeviri eğitimine ışık tutan Gideon Toury, Hans Vermeer, Hans Hönig gibi öncü çeviribilim kuramcılarının bakış açılarıyla sorgulamaya dayalı bir dersin temelinin nasıl oluşturulması gerektiği irdelenecek; daha sonra, bir eğitim psikolojisi kuramı olan Albert Bandura'nın görüşlerinden faydalanılarak gözlemleme yoluyla öğrenme konusu ele alınarak çeviri eğitimine katkısı değerlendirilecektir. Çalışmanın uygulama bölümünde, öğrencilerin görev bağlamında gerçekleştirdiği "Names" adlı bilgilendirici metin türünde yazılmış ancak kültürel öğeler de içeren metnin çevirileri ve öğrencilerin çekincelerinden kurtularak çeviri sürecinde nasıl kararlar aldıkları gösterilmeye çalışlacaktır.

\section{2. Çeviri Eğitimine Işık Tutan Öncü Çeviribilim Kuramları Işığında Sorgulamaya Dayalı Bir Dersin Temeli}

1970’lerden bu yana özerk bir bilim olarak çeviribilimden, şüphesiz nesnellik/öznellik sorgulamalarından uzak, somut ve kendine özgü kuralları olan ayrı bir disiplin olarak bahsedebiliyoruz. Sadece uygulamalı alan değil betimleyici ve kuramsal alana sahip ve her bir alanda özgün çalışmaların gerçekleştiği ayrı bir sosyal bilim alanı olan çeviribilimin bir laboratuvar gibi işleyen üç temel alanında devingen bir döngü mevcuttur.

Çeviribilimin üç temel alanı; var olan ilişkilerin betimlendiği betimleyici alan, olası ilişkilerin belirlendiği kuramsal alan ve olması gereken ilişkilerin belirlendiği uygulamalı alan birbirleriyle ilişkili bir şekilde veri üretmektedir (Öner, 1999, s. 18). James Holmes'un çeviribilim alanının adının konulduğu ve alan için bir başlangıç olarak kabul edilen "The Name and The Nature of Translation Studies” adlı makalesinde çeviri eğitimi uygulamalı alanın altında yer almaktadır (2004, çev. Koş). Ancak Öner'in de belirttiği üzere bu üç alan işbirliği içinde bir yapı göstermektedir. Dolayısıyla kuramsal alanda üretilen teorilerin bakış açısıyla uygulamalı alanda çeviri eğitimini temellendirmenin ve daha sonra betimleyici çalışmalarla yapılacak uygulamayı çok yönlü ele almanın yukarıda bahsedilen devingen döngünün bir parçası olarak hareket etmek anlamına geleceği söylenebilir. 
Çalışmada sunmak istediğimiz çeviri eğitimini temellendirecek örnek bir uygulamanın nasıl gerçekleşmesi gerektiği hakkında açıklayııı bakış açılarından ilkini bizlere Vermeer sunmaktadır. Her çeviri eyleminin bir amaç doğrultusunda yapıldığı ve bu amacın çevirmen tarafından belirlenmesi gerektiği vurgusuyla Vermeer çevirmenler için bağlama göre çeviri yapma imkânının ve bu duruma uygun çeviri stratejilerini kullanmanın önemine vurgu yapmaktadır (2008, çev. Konar). Skopos kuramına göre çevirmen her ne kadar kaynak dizge içinde oluşmuş bir kaynak metinden yola çısa da ardından, erek dizgede belirlenen bir amaç doğrultusunda ve erek dizge koşulları bağlamında kararlar alacak ve çeviriyi gerçekleştirecektir. Bu süreçte çevirmenin aldığı her karar hem kaynak dizgenin hem de erek dizgenin parçası olacaktır (Vermeer'den aktaran Akbulut, 2004, s. 135). Skopos kuramının bakış açısıyla; öğrencilere sunulacak uygulamanın sadece çeviri işinden ibaret olmadığını, aslında bu uygulamanın bir süreci kapsadığını, sadece kaynak metinden uzaklaşıp yeni bir erek metin oluşturmaktan ziyade, çeviri yaparken alacakları kararların ne denli önemli olduğunu ve uzman olarak sorumluluk almaları gerektiğini gösteren bir ortam yaratmak mümkün olabilir.

Yine skopos kuramı çerçevesinde, Vermeer, metinleri okuyan kişinin (ilk okur olarak çevirmenin) bakış açısının kültür bağımlı olduğundan ve bu durumun metnin bağlamını belirlediğinden bahseder. Hatta pek çok durumda kültür-bağımlı koşulların kişiye özgü kültür (idio-kültür), belli gruplara özgü kültür (dia-kültür) ya da belli toplumlara özgü kültür (para-kültür) koşullarının metnin yorumlanmasında etkisi büyüktür (Vermeer'den aktaran Öner,2001, s 41). Bu durumda her öğrencinin belirli bir kültüre ait olduğu ve çevirisini yapmak için kültürel özelliklere sahip bir metin seçilmesinin farklı kültürlerin çarpışmasının yeni bağlamlar üretilebilmesi açısından önemli olacă̆ı düşünülmektedir.

Diğer yandan, alanda kazanılacak uzmanlığın belirli bir süreç içinde gelişimsel olarak gerçekleşeceği de göz önünde bulundurulmalıdır. Vermeer'in uzmanlık kavramından Toury 'çalışılarak kazanılan bir beceri’ olarak bahseder. Uzmanlığa giden yolda çevirmen bir sosyalizasyon sürecinden geçmektedir.

“Toury’e göre bir gelișim süreci içinde olan çevirmenin çeviri edinci, bu sürecin her aşamasında doğal olanla sonradan edinilenin, doğuştan olanla bireysel olarak özümlenen ve toplumsal olarak belirlenenin özel bir karışımını temsil eder” (Vermeer'den aktaran Öner, 2001, s 41).

Öğrencilerin uzmanlaşabilmesi için bir diğer önemli unsur özgüven sahibi olmaları ve çeviri bilincine ulaşmalarıdır. Hans Hönig'e göre, bu durum çeviri edincinin geliştirilmesi ve çeviri makrostratejilerinin oluşturulmasıyla gerçekleşebilir (Hönig'den aktaran Öner, 2001: 42). Gerçekle gözetilerek yapılacak uygulamalarda çeviri makrostratejilerinin oluşturulmasının mümkün olduğu söylenebilir. Dolayısıyla yukarıda bahsedilen bağlamın gerekliliğini düşündüğümüzde bu bağlamları gerçek çeviri ortamlarına dönüştürmek, öğrencilerin çeviriye karşı çekinceli yaklaşımlarını ortadan kaldırabilmeleri için fırsatlar oluşturmak, çeviri sürecinde kendi kararlarını alabilmeleri için önem arz etmektedir denebilir.

\section{3. Çeviri Eğitiminde Gözlemleme Modeli}

Öncü çeviribilim kuramcılarının bakış açıları temel alınarak oluşturulacak bir çeviri dersinde uygulama yönteminin de oldukça etkili olduğu düşünülmektedir. Bu kapsamda eğitim psikolojisi alanında Albert Bandura'nın gözlemleme üzerine yaklaşımı uygulamamıza katkı sağlayabilir. Bandura'ya göre, birçok insan davranışı modeli gözlemleme yoluyla öğrenilir. Öğrenme, başkalarının gözlenmesi yani dolaylı yaşantılara dayanmaktadır. Birey başkalarının yaşantılarından öğrenir. Bu nedenle, öğrenmedeki süreçler dolaylıdır (Aliyev, 2017). Öğrenciler kendi çevirilerini yaptıklarına, gerek çeviri süreci öncesindeki araştırmalarıyla gerekse çeviri süreci esnasında kendi tercihleri doğrultusunda en uygun olanı seçmeye çalışarak belirli kararlar verirler. Her yaptıkları çeviriden şüphesiz öğrenecekleri şeyler 
farklıdır. Bunu yanı sıra başka çevirmen adaylarının tercihlerini gözlemlemenin de, öğrencilerin öğrenme süreçlerine dolaylı olarak katkı sağlayacağı düşünülmektedir. Her çevirmen adayının geçmiş yaşantısı, deneyimleri ve kazanımları farklı olacağından aynı kaynak metnin çevirisinde dahi farklı çözümler ortaya çıkacaktır. Öğrencilerin birbirlerinden, çeviri süreci öncesinde nasıl hazırlık yaptıklarını öğrenmeleri, çevirilerini takip ederek hangi durumda hangi kararları verdiklerini izlemeleri gözlemleme modeliyle sağlanabilir.

Aliyev’in aktardığı üzere Bandura’ya göre gözlemci, modelden beş şey öğrenmektedir:

1-) Birey başkalarını gözleyerek yeni bilişsel beceriler öğrenebilir.

2-) Bireyin modeli gözlemesi sonucu, geçmişte öğrenmiş olduğu yasaklar ya güçlenir ya zayıflar.

3-) Gözlemci için model sosyal yönden harekete geçirici olarak bir görev üstlenebilir. Yani gözlemci yeni değerler ve inançlar kazanabilir.

4-) Gözlemci modelden çevrenin nasıl kullanılacağını öğrenir.

5-) Gözlemci, modelin duygularını açıklama biçimini gözleyerek kendi de benzer biçimde duygularını açıllayabilir (Aliyev, 2017).

Bir çevirinin sadece bir çözümü değil, çevirmen sayısı kadar farklı çözümü olacaktır. Aynı zamanda öğrencilerin, çeviri süreçlerinde farklı kişiler tarafından farklı kararların neden ve nasıl alındığını gözlemlemeleri, empati kurmalarını sağlayacak, onlara farklı kültürlere, kimliklere sahip olsalardı kararlarının nasıl değişebileceğini gösterecektir.

Bandura'nın sosyal öğrenme kuramına göre temel ilkelerden biri öz yeterlik inancıdır.

“Öz yeterlik inancı, dört farklı öz yeterlik kaynağından etkilenerek gelișir. Bu etkilenmede en önemlisi; insanın kendi deneyimleridir. Diğer kaynaklar ise sosyal modellerin gözlenmesi ile elde edilen dolaylı yaşantılar, sözel ifadeler ve kişinin psikolojik durumudur” (Aliyev, 2017).

Öğrencilerin yaşadıkları çeviri pratiklerinin öz yeterliklerinin gelişmesine katkı sağlayacağı düşünülmektedir. Hönig’in bahsettiği makrostratejilerin oluşturulması için öz yeterliğin kazanılması; öncelikle öğrencilerin kendi çeviri deneyimleri, sınıf içinde diğer öğrencileri gözlemlemeleri ve dolaylı yaşantılarla öğrenebilmeleri, yaşadıkları çeviri süreçlerini sözel ve gerekirse yazılı ifadelerle anlatmaları ile ve diğer yandan psikolojik durumlarını göz önünde bulundurarak motive edici dönütlerle sağlanabilir. Motive edici dönütler sayesinde öğrenciler hedeflerine ulaşabildiklerini gördüklerinde, yeni çeviri pratiklerinde yeni çeviri stratejileri planlayarak yeni kararlar almaya çalışacaklardır. Aliyev'in de bahsettiği üzere öz yeterliği artırmaya yönelik senaryoların eğitimde kullanılması, kişiyi performansı için motive eder ve ona nasıl davranacağına ilişkin yol gösterir (Aliyev, 2017). Ne kadar çeşitli çeviri bağlamı, zorlayıcı görevler öğrencilere verilirse o kadar farklı yol öğrenecekleri söylenebilir.

\section{Sorgulayıcı Bir Çeviri Dersine Doğru}

Yukarıda bahsedilen kuramsal görüşlerin bakış açısıyla planlamayı hedeflediğimiz derste, kullanılacak metnin öncelikle öğrencileri zorlayacak ve onları sorgulamaya ve araştırmaya sürükleyecek özellikte bir metin olması gerektiği düşünülmektedir. Akşit Göktürk’ün Okuma Uğraşı adlı kitabındaki metne ve okumaya dair söylemleri, dersin ana materyali olan kaynak metnin seçiminde oldukça belirleyici olmuştur. Seçilecek metnin "kullanmalık" bir metin olmasının öğrencilerin metni ilk bakışta kolay algılayabilmeleri açısından uygun olduğu düşünülmektedir. 


\begin{abstract}
"Kullanmalık metinlerde soyut kavramsal örgüyü alımlayabilmek de okur için pek bir sorun yaratmaz. Gerçekte bu örgünün görülmesi zorunluluğu bile doğmaz bunlarda. Bir gazete haberi, bir kent kllavuzu, bir yemek pişirme betimi gibi kullanmalık metinlerdeki anlam birimleri, somut anlam düzeyinde, gerçek yaşam dünyasındaki karışıklıklarını bulurlar. Anlamın göndergesi her zaman bu gerçek edimle ortamı, yaşanan dünyadır” (Göktürk, 2016, s. 63).
\end{abstract}

$\mathrm{Bu}$ çalışmanın başlıca sorunsalını oluşturan, öğrencilerin çeviriye dair çekinceli yaklaşımları ve bu yönde sordukları sorular, aynı zamanda öğrencilerin kaynak metni doğru anlayamama kaygısına da sahip olduklarını düşündürtmektedir. Dolayısıyla çokça karşılaştıkları türde bir metin türünü okuyacaklarını bilmenin onları önyargılarından bir nebze de olsa uzaklaştıracağı düşünülmektedir. Diğer yandan, Göktürk’ün Roman Ingarden'dan aktardı̆̆ı üzere:

“Okur çoğunlukla, bir yapıtı okumaya, yazarın, kendi yaşantı alanından birtakım ilginç şeyleri anlatacağı beklentisiyle girişir. Çoğunlukla da, yazınsal yapıtlarda, kendi yaşamından tanıdığı nesnelerle durumların benzerlerini arar; bunları bulduğu anda yapıtı gerçek diye adlandırır" (Göktürk, 2016, s. 71).

Dolayısıyla öğrencilerin her birinin metni okurken kendilerine dair bir bilgiyi arayacakları aşikârdır. Bahsi geçen metnin haber metni türünde, çoğunluğun sahip olduğu bir bilgiyi içeriyor olması, metnin çözümlenmesi esnasında öğrencilerin arasında bilgi paylaşımıyla metni daha anlaşılır hale getirebilir. Bunun yanı sıra Göktürk’ün de dediği gibi: “Okuma edimi, baştan sona, önümüzdeki metni okuma yaşantımızın geçmişi, şimdisi, geleceği arasında bir etkileşmedir”(Göktürk, 2016, s. 138). Farklı yerlerden gelen öğrencilerin, farklı yaşantılara ve kültürlere sahip olması, farklı geçmişleri şimdiye taşıyacakları anlamına gelmektedir. Çevirmenin geçmişi, şimdisi ve geleceği ile bağlantı kurması; Toury'nin söylediği gibi; bir gelişim sürecinde olan çevirmenin çeviri edincini temsil etmekte, geçmiş (doğal olan), şimdi (sonradan edinilen), doğuştan olan (kimliği), bireysel olarak özümlenen ve toplumsal olarak belirlenenin (şimdisi) karışımı geleceği, yani nihai çeviriyi ortaya çıkaracaktır (Bengi-Öner, 2001: 41), denebilir.

Çevirmen, çeviri işinden önce bir okur olarak metinle karşllaşmaktadır. Bir okur olarak çevirmenin yazınsal okuma etkinliğinin Göktürk'e göre iki yönü vardır:

“Birinci yön, metiniçi doğrultuludur, bütün metiniçi dilsel öğelerin ilişkilerini kapsar. İkinci yön ise metindışı doğrultuludur, yapıtın içinde oluştuğu toplumsal tarihsel bağlamı, bir de okurun geçmişini şimdisini, bütün bir yaşantı birikimini kapsar. Okuma ediminin bu iki yönüyle, yazın yaşamı, yaşam da yazını sürekli etkiler" (Göktürk, 2016, s 150).

Çeviri öğrencilerinin haber metni olması nedeniyle kolayca kavrayabilecekleri metiniçi öğelere ve geçmiş yaşantılarını da içine katabilecekleri ve güncel yaşantılarında karşılaşmış olabilecekleri bilgileri uyarlayabilecekleri metindışı doğrultuya da sahip, iki yönlü bir okumanın gerçekleşebileceği bir etkinlik, örnek uygulamamızı oluşturacaktır. Örnek uygulama yedi temel adımdan oluşmaktadır:

\title{
1. Kaynak Metni Okuma Anlama
}

2. Kaynak Metnin İşlevini Saptama

3. Görevler Bağlamında Çevirmenin Amacının Belirlenmesi (2 farklı amaç belirlenmiştir)

4. Erek Metnin Olası İşlevlerini Saptama

5. Farklı İşlevlere Yönelik Çeviri Stratejileri Hakkında Tartışma 


\section{Tamamlanan Çeviri Süreçlerine Yönelik Paylaşım}

\section{Yapılan Çevirilerin Okunması ve Karşılaştııılması}

Kaynak metin, Richard Rodriguez tarafından NewsHour'da yazılan Names adlı bir köşe yazısıdır. Seçilen metin, Katharina Reiss'in (Metin türlerine vurgu yaparak 1970'lerde çeviribilim için önemli bir bakış açısı oluşturan işlevsel yaklaşımına göre) işlemsel metin (operative text type) özellikleri de taşıyan bilgilendirici metin (informative text type) türünde bir metindir. Metnin, Amerika'da yaşayan İspanyolların isimlerinin günlük yaşamda Latinceleştirilmesi üzerine bir eleştiri sunmak amacıyla yazıldığı söylenebilir.

Dönemin başında verilen bu metni, öğrencilerden sinıfa gelmeden önce okumaları, gerekirse araştırmaları istenmiştir. Daha sonra sınıf içi tartışmada metiniçi özellikler ele alınarak metnin ne tür bir işleve sahip olduğu belirlenmiştir. Ardından çeviri işinin neden yapılacağına dair iki gerçek durum oluşturulmuş ve iki farklı bağlam çerçevesinde görevler belirlenmiştir. Bu görevler şu şekildedir:

Görev 1: İngilizce yazılan bu metin Türkçe bir gazetede haber metni olarak yer alacaktır. Kaynak metnin amacını ve yazarının üslubunu gözeterek metni Türkçeye çeviriniz.

Görev 2: İngilizce yazılan bu haber metni Türkçede en çok kullanılan isimler ve kökenleriyle ilgili özel bir dergi sayısında Türkçe olarak yer alacaktır. Metnin içeriğinden uzaklaşmadan kaynak metni Türk toplumuna uyarlayınız.

Görevler iki farklı gruba ayrılan öğrencilere verilmiştir. Ardından çeviriyi sınıfa gelmeden önce yapacakları için, iki farklı görev doğrultusunda oluşacak iki erek metnin olası işlevlerinin ve kullanacakları stratejilerinin neler olacağı tartışılmıştır.

1. Olası İşlev: Kaynak metindeki bilgilerin eksiksiz ve doğru olarak aktarılmasını sağlamak.

2. Olası İşlev: Kaynak metnin yazarının kendi kültüründe sağlamış olduğu etkiyi hedef kültürde de sağlamak.

\subsection{Yapılan Çevirilerden Örnekler}

Birinci görev doğrultusunda yapılan çevirilerden örnekler aşağıdaki tabloda karşılaştırmalı olarak yer almaktadir:

\begin{tabular}{|l|l|}
\hline Kaynak Metin & Erek Metin \\
\hline $\begin{array}{l}\text { Many Americans are troubled regarding the } \\
\text { Latinization of the United States, the ubiquitous } \\
\text { brown faces in the crowd, Spanish everywhere. }\end{array}$ & $\begin{array}{l}\text { Birçok Amerikan Amerikanın latinleştirilmesi } \\
\text { sorunuyla karşı karşıya, toplumda her yerde } \\
\text { görülebilen kahverengi yüzlerle İspanya her } \\
\text { yerde (S.O.). }\end{array}$ \\
\hline $\begin{array}{l}\text { On nativist talk radio, in the speeches of } \\
\text { politicians, a legend of illegality as old as }\end{array}$ & $\begin{array}{l}\text { Tarafsız bir radyoda politikacinın konuşmasında } \\
\text { kovboy amerikası kadar eski olan kanunsuzluk }\end{array}$ \\
\hline
\end{tabular}




\begin{tabular}{|c|c|}
\hline $\begin{array}{l}\text { cowboy America attaches to anyone related to } \\
\text { Latin America, whether or not one is legally } \\
\text { here. }\end{array}$ & $\begin{array}{l}\text { Latin Amerikaya bağlı olan herkesle } \\
\text { bağdaştırılıor, yasal olarak burada olması } \\
\text { önemsiz olarak (S.O.). }\end{array}$ \\
\hline $\begin{array}{l}\text { It made the news recently that «Garcia» and } \\
\text { Rodriguez» are now among the top } 10 \text { most } \\
\text { common American surnames. We Hispanics } \\
\text { have become a people whose presence gets told } \\
\text { by such numbers, our ascending numbers. }\end{array}$ & $\begin{array}{l}\text { Garcia ve Rodriguez amerikanın en yaygın } 10 \\
\text { soyadı arasına girdi. Biz latinlerin sayıları } \\
\text { birçoklar tarafından konuşulur oldu (S.O.). }\end{array}$ \\
\hline $\begin{array}{l}\text { In the } 1990 \text { cencus, Garcia ranked 18th, } \\
\text { Rodriguez 22nd. A decade later, the Garcias } \\
\text { have ascended } 10 \text { rungs, the Rodriguezs 13. this } \\
\text { numerical rise means simply that descendants } \\
\text { of the Spanish empire are now living alongside } \\
\text { descendants of the English empire in places like } \\
\text { Kentucky and Iowa, where they have rarely } \\
\text { lived side-by-side before. }\end{array}$ & $\begin{array}{l}1990 \text { nüfus sayımında, Garcia 18. , Rodriguez } 22 . \\
\text { geldi. } 10 \text { yıl sonra Garcia'lar 10, Rodriguez'ler } 13 \\
\text { basamak atladı. Bu sayısal artış sadece İspanyol } \\
\text { imparatorluğu neslinin İngiliz imparatorluğu } \\
\text { nesliyle, önceden nadiren birlikte yaşadıkları } \\
\text { Kentucky ve Iowa gibi yerlerde birlikte } \\
\text { yaşadıkları anlamına geliyor (B.Y.). }\end{array}$ \\
\hline $\begin{array}{l}\text { Often, as Hispanics grow assimilated in the } \\
\text { U.S., paradoxically they give their surnames } \\
\text { baroque pronounciations. Tiffany Rodriguez } \\
\text { goes to college and becomes «Tiffany } \\
\text { Rodriguez.» }\end{array}$ & $\begin{array}{l}\text { Çoğunlukla, Latinler A.B.D. de benzeştikçe } \\
\text { paradoksal olarak soy isimlerine barok telaffuz } \\
\text { etkisi veriyorlar. Tiffany Rodriguez üniversiteye } \\
\text { gidiyor ve "Tiffany Rodriguez" oluyor (B.Y.). }\end{array}$ \\
\hline
\end{tabular}

Tablo1: Birinci görev doğrultusunda yapılan çevirilerden örnekler

Yukarıdaki tabloda yer alan çevirilerde öğrencilerin mümkün olduğunca kaynak metne sadık çeviri yapmaya çalıştıkları gözlemlenmiştir. Kaynak metindeki bilgileri koruyarak, Türkçe'de benzeri bir anlamsal düzey oluşturmaya çalışmışlardır. Haber metni olduğu için cümle yapılarında estetik bir kaygı gütmeden, sözcüklere gerçek anlamlarıyla karşılık bulmuşlardır. Çeviri yapmadan önce belirlenen hedefler doğrultusunda, göreve ve bağlama uygun çeviri yaptıkları söylenebilir.

İkinci görev doğrultusunda yapılan çevirilerden örnekler aşağıdaki tabloda karşılaştırmalı olarak yer almaktadir:

\begin{tabular}{|l|l|}
\hline Kaynak Metin & Erek Metin \\
\hline $\begin{array}{l}\text { Many Americans are troubled regarding the } \\
\text { Latinization of the United States, the ubiquitous } \\
\text { brown faces in the crowd, Spanish everywhere. }\end{array}$ & $\begin{array}{l}\text { üzerindeki Arapça etkisinden habersiz (İ.U.). } \\
\text { ürk, en çok kullanılan isimlerin }\end{array}$ \\
\hline
\end{tabular}




\begin{tabular}{|c|c|}
\hline $\begin{array}{l}\text { On nativist talk radio, in the speeches of } \\
\text { politicians, a legend of illegality as old as cowboy } \\
\text { America attaches to anyone related to Latin } \\
\text { America, whether or not one is legally here. }\end{array}$ & $\begin{array}{l}\text { Bir halk radyosunda veya haberlerde pek yer } \\
\text { almasa da, bazı insanlar bunun farkında } \\
\text { (İ.U.). }\end{array}$ \\
\hline $\begin{array}{l}\text { It made the news recently that «Garcia» and } \\
\text { Rodriguez» are now among the top } 10 \text { most } \\
\text { common American surnames. We Hispanics } \\
\text { have become a people whose presence gets told } \\
\text { by such numbers, our ascending numbers. }\end{array}$ & $\begin{array}{l}\text { İncelendiği zaman kadın isimlerinde en çok } \\
\text { kullanılan iki ismin «Fatma» ve «Ayşe» } \\
\text { olduğu görülüyor. Ki bu iki isim de Arapça } \\
\text { kökenli. Erkek isimlerinde en çok kullanılan } \\
\text { iki ismin ise «Mehmet» ve «Mustafa» olduğu } \\
\text { görülüyor. Bu iki isim de yine Arapça kökenli } \\
\text { (İ.U.). }\end{array}$ \\
\hline & $\begin{array}{l}\text { Ülkenin çoğu yerinde Suriyeliler isimleriyle } \\
\text { değil de «Suriyeli» olarak anılıyordu. (S.B.) }\end{array}$ \\
\hline $\begin{array}{l}\text { Often, as Hispanics grow assimilated in the U.S., } \\
\text { paradoxically they give their surnames baroque } \\
\text { pronounciations. Tiffany Rodriguez goes to } \\
\text { collge and becomes «Tiffany Rodriguez.» }\end{array}$ & $\begin{array}{l}\text { Ayrıca bizi, isimlerimizle çağırmamalarıla } \\
\text { birlikte, kendi isimlerimizi Türkçe'ye } \\
\text { uyarlıyorlar. Tipkı Mohammed’in } \\
\text { Muhammed, Muhammed'in de «Momi» } \\
\text { olarak kısaltılması gibi. (S.B.) }\end{array}$ \\
\hline $\begin{array}{l}\text { Because Hispanics are an ethnic category joined } \\
\text { loosely by culture, Hispanic advertising agencies } \\
\text { and Spanish- language television stations daily } \\
\text { impress on how our culture identity is tied to the } \\
\text { language of Spain. }\end{array}$ & $\begin{array}{l}\text { Suriyelilerin Türk kültürüyle olan bağı çok } \\
\text { sıkı değildir, ancak Arap kültürü ile daha } \\
\text { yakın bir ilişki içindedir. Gazetelerde de } \\
\text { Suriyelilerin Arapça ile nasıl bir bağının } \\
\text { olduğu tartışılmaktadır. (S.B.) }\end{array}$ \\
\hline
\end{tabular}

Tablo2: İkinci görev doğrultusunda yapılan çevirilerden örnekler

İkinci görev doğrultusunda yapılan çevirilerde ise öğrencilerin mümkün olduğunca kaynak metindeki bilgileri uyarlamaya çalıştıkları görülmektedir. Kendi bilgilerini, kültürlerini, ait oldukları kültürel katmanların getirilerini katarak yeni bir metin ortaya çıkarmışlardır. Kaynak metindeki "Garcia" ve "Rodriguez" gibi yabancı isimler "Fatma”, "Ayşe”, "Mustafa", "Mehmet" isimlerine uyarlanmıştır. Haber metninde verilen İspanyolların Amerika'da yaşadıkları durumla ilgili bilgiler göz önünde buldurularak, "Suriyeliler" gibi farklı kültürlerin ülkemizde yaşadığı zorlu duruma dikkat çekilmiştir. Kaynak metinde yer alan haber bilgileri, erek metinde yer alması gereken haber bilgilerinin sinırlamalarını oluşturmuştur. Dolayısıyla bu sınırlama, bilgilerin karşlıklarını vermek açısından da bir kontrol mekanizması oluşturmaktadır. Çevirilerde verilen görev doğrultusunda sınırlayıcı bir çerçeve içinde 
benzer konular hakkında bir uyarlama yapılmıştır. Ancak, erek okura daha anlaşılır bir okuma ortamı sunmak amacıyla, kaynak metinde yer almayan açılamalara erek metinlerde yer verildiği görülmektedir (İkinci görev doğrultusunda yapılan çevirilerde dördüncü satırda görüldüğü gibi). Çeviri yapmadan önce gerçekleşen sınıf içi tartışmalarda alınan kararların yansımasını, çeviri stratejileri olarak erek metinlerde görmek mümkündür.

\subsection{Görev Doğrultusunda Yapılan Çeviri Sürecine Dair Örnekler}

Çevirilerin sınıfta okunarak görev doğrultusunda belirlenen işleve ulaşıp ulaşmadığı tartışılmıştır. Farklı çözümlere kavuşan her bir çeviri metin, şüphesiz farklı birer çeviri sürecinden geçmiştir. Çeviriler kadar çeviri süreçlerinin de sınıfta paylaşılmasının, farklı çeviri yollarının gözlemlenmesi açısından önemli olduğu düşünülmektedir. Öncelikle sınıf içi tartışma ortamında öğrencilere aşağıdaki soru sorulmuş, daha sonra öğrencilerin bu paylaşımlarını yazılı hale getirmeleri istenmiştir.

Soru: "Names" adlı metni İngilizceden Türkçeye çevirirken metnin türünü, içeriğini, yazılma amacını ve bağlamını yaratan göreviniz doğrultusunda verdiğiniz genel kararlar nelerdi? Çeviri sürecinde yaşadığınız başlıca problemler nelerdi ve bunları çözmek için ne tür yöntemler kullandınız?

Birinci Görev Doğrultusunda Yapılan Çeviri Sürecine Dair:

“İlk yaptığım şey kaynak metne uygun olması için yapabileceklerimi düşünmekti. Yani kaynak metni erek dizgeye nasıl en kolay şekilde en anlaşılır șekilde geçirebilirim diye başladım. Çeviri sürecinde en çok zorlandığım şey ise erek okuyucunun anlayabileceği, kavrayabileceği rahatlıkla okuyabileceği akıcılığı sağlayabilmekti. Bunları çözmek içinse kelime tercihlerim ilk yardımcım oldu, doğru kelimeleri seçtiğimde bu sorunları çözebildiğimi farkettim” (D.D.).

Yukarıdaki örnek birinci görev doğrultusunda yapılan çevirilerin ortak özelliklerini taşımaktadır. Cümle yapıları ve bilgiler çeviri esnasında sorun yaratmasa da Türkçede bilgileri anlaşılır kılmak onları zorlamıştı. Çünkü erek okura anlaşılır metin sunmak herkesin ortak amacıydı. Kaynak metnin bilgisini, erek okur için değiştirmeden ama yine de daha anlaşılır hale getirmek bu görevin zorlayıcı yönlerinden biriydi.

İkinci Görev Doğrultusunda Yapılan Çeviri Sürecine Dair:

Örnek 1:

"Bilgilendirici bir metin türüydü ve bunu göz önünde bulundurarak çeviri yaptım. Ama amacım doğrultusunda bir bakıma yeni bir metin oluşturdum. Kaynak metindeki verilen mesajı erek kültürün kolayca anlayabileceği bir şekilde vermeye çalıştım. Öncelikle kaynak metindeki olayı erek metinde yansıtabilmek oldukça zordu. Farklı karşılıklar ve örnekler bulmak zorunda kaldım. Birçok yönden konunun karşılığı bunabilirdi fakat ben daha politik olanı tercih ettim: bunun sebebi ise onun hakkında daha fazla bilgiye sahip olmamdı. Konuya biraz hakim olduğum için örnek vermede işim kolaylaştı. Kaynak metin dil oyunlarıyla dolu olduğu için erek dizgede karşılığını bulmak, yaratmak yine zordu. Bunu çözmek için de kendi dilimizdeki dil oyunlarından yararlandık. Metin beni zorladığ kadar eğlenceliydi de" (S.B.).

Örnek 2:

"Metin bilgilendirme amacıyla yazılmıştı ve ben de bu amacın dışına çıkmadan çevirmeye çalıştım. Metindeki isim ve yer adlarını erek okurun rahatça anlayabilmesi için erek kültüre uygun şekilde değiştirdim. Yaşadı̆̆ım en büyük zorluk kaynak metindeki verilenlerin karşılığını bulmaktı. Görevimiz özgür bir şekilde çevirmekti; yeni bir metin de yazabilirdim. Ancak ben kaynak metinden fazla uzaklaşmadan çevirmeye karar verdim. Çünkü erek okurun kaynak metinde verilen bilgiyi almasını istedim. Zorluk yaşadığım ifadelerin karşılıklarını bulmak için erek kültürdeki isimleri, yaşanmış olayları ve yer adlarını araştırdım. Aralarında benzerlik olduğunu görmek çeviriyi yaparken daha rahat hissetmemi sağladı" (T.Ö.). 
Örnek 3:

“Metni çevirmeden önce inceledim ve metni Türkiye'de yaşanan benzer olaylara uyarlamaya karar verdim. Fakat metnin yapısını, bağlamını ve anlatmak istediği mesajı korumaya gayret gösterdim. Böylece bir anlam bütünlüğü oluşturmaya çalıștım. Metnin bazı yerlerinde az da olsa ekleme çıkarma yapmak zorunda kaldım böylece daha anlamlı bir hale geldiğine inanıyorum. Zorlandı̆̆ım yerlerden birisi de isim bulma konusuydu. Doğru ismi seçmek için araştırma yaptım. İstatistiki verileri isimlerin kökenlerini ve Türkiye'deki konumunu inceledim. Siyasi göndermeleri Türkiye'dekilerine uyarladım” (C.S.).

İkinci görev doğrultusunda yapılan çeviri sürecinde, örnek 1'de görüldüğü üzere, uyarlanacak kültürü iyi tanımak bilgilerin karşılıklarını bulmak açısından öğrenciye kolaylık sağlamıştır. Örnek iki ve üçte ise vurgu araştırma yapmak üzerinedir. Öğrencilerin çeviri yapmadan önce araştırma yapmaya ihtiyaç duydukları görülmektedir. Erek toplumda benzerlikleri ararken, karşılaştıkları farklılıklara çözüm bulmak bu görevin en zorlayıcı yönü olarak görülüyor. Öğrencilerin, çevirmenin aynı zamanda bir araştırmacı olduğunu da ortaya koyan söylemlerinin, oluşturacakları çevirmen kimliğinin önemli ve ayrılmaz bir parçası olacağı düşünülmektedir.

\section{Sonuc}

Gerçek çeviri ortamları oluşturularak yapılacak uygulamalarda, öğrenciler empati kurarak hangi durumla karşılaştıklarında hangi kararları almaları gerektiğini öğrenebilirler. Bu sayede öğrencilerin, soyut olarak değil somut olarak öncü kuramlarda bahsedilen temel çeviri gerçeklerini ve çevirinin döngüsel ve yorumlamaya dayalı bir süreç olduğunu fark etmeleri sağlanabilir. Bahsedilen gerçek çeviri ortamlarında, farklı çeviriler gözlemlenerek dolaylı yaşantılara dayanan çeviri süreçleri öğrenilebilir, alınan bireysel kararlar başkalarınınkiyle karşılaştırılarak değerlendirilebilir.

Diğer yandan, kültürel farkındalık gerektiren metinlerle, çevirinin doğası gereği belirli kültürel bağlamlar içerisinde gerçekleşen bir yorumlama işi olduğu bilinci edinilebilir. Bu sayede öğrenciler uyarlama yapma şansı elde edecek, erek okura daha anlamlı metinler sunabilmek için araştırmalar yapacaklardır. Araştırmaya yönlendirici çeviri pratikleri yoluyla sahip oldukları bilgiler ile sonradan edindikleri bilgiler ve toplumsal olarak belirlenen durumlar bir araya getirilerek öğrencilerin kendi karar mekanizmalarını oluşturmaları ve sorumluluk almaları sağlanabilir.

Son olarak, öğrenciler yaptıkları çevirilerin, sadece erek dizgenin bir parçası olmasından ziyade kendi düşüncelerinin de birer yansıması olduğunu görebilirler. Yani sadece kaynak dizge ve erek dizge arasında aracılık yapmaktan ziyade, kendi etkileriyle bir erek metin yaratıldığını ve kendi izlerini mutlaka erek metne kattıklarını fark edebilirler. Sınırları belli olmayan bir çeviri tanımından hareketle, soyut değil somut örneklerle çevirmen adaylarını geleceğe hazırlama amaçlı, sorgulayıcı bir ders izlencesiyle öğrenciler, eleştirel düşünerek profesyonel çevirmenlik yaşamlarında olası yeni sorulara/sorunlara cevaplar bulmayı öğrenebilirler.

\section{Kaynaklar}

Akbulut, Ayşe Nihal (2004) Söylenceden Gerçekliğe: Çeviri Eğitimine İlişkin Düşünce, Gözlem ve Uygulamalar. İstanbul: Multilingual Yayıncllı

Aliyev, Ramin (2017). «Eğitimi Psikolojisi « içinde Böl 13 Sosyal Bilişsel Öğrenme. Edt. Şerife Işık. Pegem Akademi Yayınları. (s 437-455)

Birkan-Baydan, Esra (2011). "Yapısalcılık Sonrası Kuramsal Görüşler Doğrultusunda Çeviri Eğitimine Giriş: Toplumsal Oluşumcu Yaklaşım Işı̆̆ında Uygulama Örnekler”, Yıldız Teknik Üniversitesi Basılmamış Doktora Tezi. İstanbul 
Bengi-Öner, I. (1999). “Çeviri Edebiyat Örnekleriyle Betimleyici Çeviribilim”. Çeviri Bir Süreçtir. Ya Çeviribilim?, İstanbul: Sel Yayıncılık

Bengi-Öner, Işın (2001). Çeviri Kuramlarını Düşünürken, İstanbul: Sel Yayıncılık.

Göktürk, Akşit (2016). Okuma Uğraşı. İstanbul: Yapı Kredi Yayınları.

Holmes, James S., (2004) "Çeviribilimin Adı Ve Doğası", Çev.: Ayşenaz Koş, Çeviri(Bilim) Nedir?:Başkasının Bakışı İçinde, Yay. Haz. Mehmet Rifat, İstanbul, Dünya Yay. Ss. 165-182

Reiss, K. (1981/2000). “Type, kind and individuality of text: decision making in translation”, translated by S. Kitron in L. Venuti (ed) (2000), pp. 160-71.

Vermeer, Hans J. (2008). “Çeviride Skopos Kuramı, (Çev.) Ayşe Handan Konar. İstanbul: İş Bankası Kültür Yayınları

Bu çalışma, 2017-2018 eğitim öğretim yılının bahar döneminde IMT 142 Genel Metinler Çevirisi II dersini alan 1. sınıf öğrencilerinin (Samed Okuyan, Boran Yılmaz, İpek Uzun, Seyithan Barut, Derya Doğdu, Tuğçe Özer, Cem Sezer) "Çeviri Sürecinde Öğrencilerin Kendi Kararlarını Alabilmeleri” konulu yapacağım çalışmalarımda, kendi çeviri örnekleri ve çeviri sürecine dair düşüncelerini gönüllü olarak paylaşmama izin vermeleriyle gerçekleşmiştir. Bu öğrenciler, bahsi geçen dersi ikinci dönemde almadan önce, birinci dönemde Genel Metinler Cevirisi I ve Çeviribilime Giriș I derslerini aldıkları için, çeviriye giriş niteliğinde kuramsal bilgiye ve çeviri konusunda kendilerini ifade edebilecek belirli bir terminolojiye sahiptirler. (Çalışmanın başlangıcında, öğrencilerin çekincelerini ortaya koymayı amaçlayan soruların Mart ayında, ikinci dönemin başında sorulmasının nedeni de öğrencilerin kendilerini ikinci dönem daha rahat ifade edebilecek olmalarıdır.) Genel Metinler Çevirisi II dersi kapsamında, öğrencilere dönemin başında bir ders planı sunularak, dönem boyunca ne tür metinlerle karşılaşacakları hakkında ve yapılacak çalışmayla ilgili ön bilgi verilmiştir. Çalışmada bahsedilen akış planı adım adım uygulanarak, öğrencilerin çeviri sürecine dair sözlü ifadeleri yazılı olarak da istenmiştir. Yazılı ifadeler incelendiğinde görev çerçevesinde ayrılan iki farklı grubun kendi içinde benzer özellikler gösterdiği saptanmıştır. Diğer yandan bahsedilen dersin amacının oluşturulması esnasında, bu çalışmayla benzer özellikler gösteren, Esra Birkan Baydan’ın 2011 ylında tamamladığı "Yapısalcılık Sonrası Kuramsal Görüşler Doğrultusunda Çeviri Eğitimine Giriş: Toplumsal Oluşumcu Yaklaşım Işığında Uygulama Örnekler” başlıklı basılmamış doktora tezinden ne tür metinler seçilmesi gerektiği konusunda faydalanılmıştır. 